\title{
Absorption of Calcium and Magnesium to the Fruit Body of Aragekikurage (Auricularia polytricha (Mont.) Sacc.) from Sawdust Culture Media Supplemented with Calcium and Magnesium Salts
}

\author{
Takeo TABATA ${ }^{1}$ and Tetsuya OGURA ${ }^{2}$ \\ ${ }^{1}$ Kobe Women's University Seto Junior College, 721 Kannonji, Seto-cho, Akaiwa-gun, Okayama 709-0863, Japan \\ ${ }^{2}$ Departamento de Química, CEN, Universidad Autónoma de Guadalajara Apdo. Postal 1-440, Guadalajara, Jalisco, Mexico
}

Received October 3, 2002; Accepted June 14, 2003

\begin{abstract}
Auricularia polytricha was incubated in potato-sucrose-agar (PSA) and in a sawdust medium supplemented with $\mathrm{Ca}$ or Mg salts. The mycelia grew well on the PSA supplemented with Ca sulfate, Ca phosphate, Mg sulfate and Mg chloride. On sawdust medium, the supplementation with Ca phosphate, Ca carbonate, Mg sulfate or Mg carbonate resulted in good mycelial growth. The Ca content of fruit body grown on the sawdust medium was increased 1.1-1.5 times by supplementation of 1-5\% of Ca phosphate or Ca carbonate. The Mg content was increased 1.7-2.2 times by $0.5 \%$ of Mg carbonate, $\mathrm{Mg}$ hydroxide, $\mathrm{Mg}$ sulfate and $\mathrm{Mg}$ chloride.
\end{abstract}

Keywords: Aragekikurage (Auricularia polytricha), mycelial growth, Mg-Ca-supplementation, Mg-Ca-absorption

Auricularia polytricha (Aragekikurage in Japanese) is one of the wood-rot fungi of the broadleaf tree. Though A. polytricha is a mushroom which is as important for Chinese-cooking as Auricularia auricula (Kikurage in Japanese), in many cases, the mushroom is sold in the market without distinguishing it from $A$. auricula. It generally resembles $A$. auricula, however, it is covered with small grayish brown hair, and the underside is darkish brown or light brown (Imazeki et al., 1970).

In research of $A$. polytricha, the culture media (Kinjo \& Kondo, 1979; Lin, 1991), the components (Yoshida et al., 1986, 1996; Lee et al., 1995; Cheung, 1997; Mau et al., 1998), antitumor activity (Misaki et al., 1979), antioxidative activity (Zhou \& Yu, 2000) and effects of cholesterol (Arakawa et al., 1977; Tamaki et al., 1997) have been reported.

The $\mathrm{Ca}$ and $\mathrm{Mg}$ content of mushrooms are generally low in comparison with vegetables and seaweed (Kagaku Gijitsu-cho, 1995). However, it is known that in the Jew's-ear mushrooms the content of $\mathrm{Ca}$ and $\mathrm{Mg}$ in mushrooms is very high (Kawai et al.,1986; 1990). Apparently, Ca and Mg are especially necessary for the maintenance of the human physiological function.

Several studies have been directed on the absorption of heavy metals from sawdust culture media by the mushrooms Pleurotus ostreatus, Hypsizigus marmoreus, Pholiota nameko, Flammulina velutipes and Ganoderma. lucidum (Yasui et al., 1988; Sasaki et al., 1995; Tham et al., 1999). However, the absorption of Ca and $\mathrm{Mg}$ by $A$. polytricha from sawdust culture medium supplemented with these salts has not yet been established. Previously, we studied $P$. ostreatus and $P$. nameko in PSA and in sawdust medium supplemented with $\mathrm{Ca}$ or $\mathrm{Mg}$ salts (Tabata \& Shinohara, 1995; Tabata \& Ogura, 2003).

In this paper, the mycelial growth of $A$. polytricha was studied in PSA and in sawdust medium supplemented with diverse $\mathrm{Ca}$ or $\mathrm{Mg}$ salts; the absorption of these elements from the sawdust into

E-mail: t.tabata@alpha.ocn.ne.jp the fruit body is discussed. In addition, the $\mathrm{pH}$ change of medium supplemented with these salts during mycelial growth was studied.

\section{Materials and Methods}

The strain of $A$. polytricha was purchased from the Onuki Kinjin Co., Utsunomiya-shi, Japan. The mushrooms were cultivated in the farm of Kobe Women's University Biotechnology Institute. Ca chloride $\left(\mathrm{CaCl}_{2} \cdot 2 \mathrm{H}_{2} \mathrm{O}\right), \mathrm{Ca}$ sulfate $\left(\mathrm{CaSO}_{4} \cdot 2 \mathrm{H}_{2} \mathrm{O}\right)$, Ca carbonate $\left(\mathrm{CaCO}_{3}\right), \mathrm{Ca}$ phosphate $\left(\mathrm{CaHPO}_{4} \cdot 2 \mathrm{H}_{2} \mathrm{O}\right), \mathrm{Mg}$ sulfate $\left(\mathrm{MgSO}_{4} \cdot 7 \mathrm{H}_{2} \mathrm{O}\right), \mathrm{Mg}$ chloride $\left(\mathrm{MgCl}_{2} \cdot 6 \mathrm{H}_{2} \mathrm{O}\right), \mathrm{Mg}$ carbonate (approximate composition $4 \mathrm{MgCO}_{3} \cdot \mathrm{Mg}(\mathrm{OH})_{2} \cdot 5 \mathrm{H}_{2} \mathrm{O}$ ), and $\mathrm{Mg}$ hydroxide $\left(\mathrm{Mg}(\mathrm{OH})_{2}\right)$ were purchased from Wako Pure Chemical Industries Co. and used without further purification.

Mycelial growth on the PSA supplemented with $\mathrm{Ca}$ or $\mathrm{Mg}$ salts The PSA medium was supplemented with a Ca salt to $0.5,1$ or $10 \%$, or with an $\mathrm{Mg}$ salt to $0.5,1$ or $5 \%$. The $\mathrm{Ca}$ and $\mathrm{Mg}$ salts tested were $\mathrm{Ca}$ chloride, $\mathrm{Ca}$ sulfate, $\mathrm{Ca}$ carbonate, $\mathrm{Ca}$ phosphate, $\mathrm{Mg}$ sulfate, $\mathrm{Mg}$ chloride $\mathrm{Mg}$ carbonate and $\mathrm{Mg}$ hydroxide. Then, the medium was autoclaved at $120^{\circ} \mathrm{C}(1.0 \mathrm{~kg} /$ $\mathrm{cm}^{2}$ ) for $15 \mathrm{~min}$ and poured into petri dishes. A. polytricha was previously grown on the PSA medium without supplementation in a petri dish. Agar discs ( $7 \mathrm{~mm}$ in diameter) covered with wellgrown mycelia from a 7-day-old colony were placed at the center of each plate supplemented with $\mathrm{Ca}$ or $\mathrm{Mg}$ salt. The plate was then incubated for 7 days at $25^{\circ} \mathrm{C}$ in the dark and the diameter of the mycelial growth was determined. All experiments were conducted with three replicates per treatment.

Mycelial growth on the sawdust media supplemented with Ca or Mg salts A mixture of beech sawdust and rice bran (4:1 w/w) was supplemented with 1,5 , or $10 \%$ of a Ca salt, or with $0.5,1$ or $5 \%$ of a Mg salt. Then, tap water was added to the mixture to give a moisture content of $70 \%$, and it was mixed well for homogeneity. Approximately $30 \mathrm{~g}$ of the medium was tightly packed into a petri dish. The dish was autoclaved at $120^{\circ} \mathrm{C}$ for 60 min, and allowed to cool for about $5 \mathrm{~h}$. A mycelium disc was put 
on the center of the sawdust medium in the same method as the agar medium described above and allowed to incubate for 10 days at $25^{\circ} \mathrm{C}$ in the dark. The diameter of the mycelial growth was measured.

Harvesting of the fruit body of A polytricha from sawdust media supplemented with $\mathrm{Ca}$ or $\mathrm{Mg}$ salts Sawdust medium supplemented with 1, 5 or $10 \%$ of Ca carbonate or Ca phosphate, or $0.5 \%$ of $\mathrm{Mg}$ salts was prepared as described above. A heatresistant polypropylene culture bag containing approximately $800 \mathrm{~g}$ of the medium was autoclaved at $120^{\circ} \mathrm{C}\left(1.0 \mathrm{~kg} / \mathrm{cm}^{2}\right)$ for $120 \mathrm{~min}$. After cooling for overnight, it was inoculated with 10 to $14 \mathrm{~g}$ of $A$. polytricha mushroom seed and incubated at $25^{\circ} \mathrm{C}$.

Approximately 80 days after the inoculation, the mycelia spread thoroughly over the medium. Then, the bag was opened, the culture was sprinkled with water once a day to keep it moist and to maintain the relative humidity at about $90 \%$. The temperature during the active fruiting period was kept between 25 and $28^{\circ} \mathrm{C}$. The fruit body of $A$. polytricha were harvested and dried in a forced air-oven at $60-70^{\circ} \mathrm{C}$ for $70 \mathrm{~h}$. A homogeneous sample was prepared by grinding the dried fruit body using a stainless steel mill.

Analysis of $\mathrm{Ca}$ and $\mathrm{Mg}$ contents in fruit body $\mathrm{Ca}$ and $\mathrm{Mg}$ were analyzed as described previously (Tabata \& Shinohara 1995). Silicic acid was removed from the ashed samples by $\mathrm{HCl}$ digestion. Atomic absorption spectrophotometry (Shimadzu AA6400F) was used to determine the elements, adding $\mathrm{SrCl}_{2}$ and employing a nitrous oxide-acetylene flame.

Analysis of $\mathrm{Ca}$ and $\mathrm{Mg}$ contents in sawdust medium One gram of a sawdust medium placed in a quartz crucible was calcinated carefully using a Bunsen burner and kept at $550^{\circ} \mathrm{C}$ in a muffle furnace for $5 \mathrm{~h}$. Ca and $\mathrm{Mg}$ were determined as described above. It was found that $100 \mathrm{~g}$ of the sawdust medium described above (wet weight) contained $64.4 \mathrm{mg}$ of $\mathrm{Ca}$ and $82.1 \mathrm{mg}$ of $\mathrm{Mg}$. $\mathrm{Ca}$ and $\mathrm{Mg}$ contents in sawdust used in this experiment were found to be 279 and $35 \mathrm{mg} / 100 \mathrm{~g}$ (dry weight), respectively.

\section{Results and Discussion}

The mycelial growth of $A$. polytricha was studied supplementing a $\mathrm{Ca}$ or $\mathrm{Mg}$ salt to PSA and sawdust medium. The absorption of these elements to the fruit bodies was studied growing the mushroom on sawdust medium supplemented with the $\mathrm{Ca}$ or $\mathrm{Mg}$ salts.

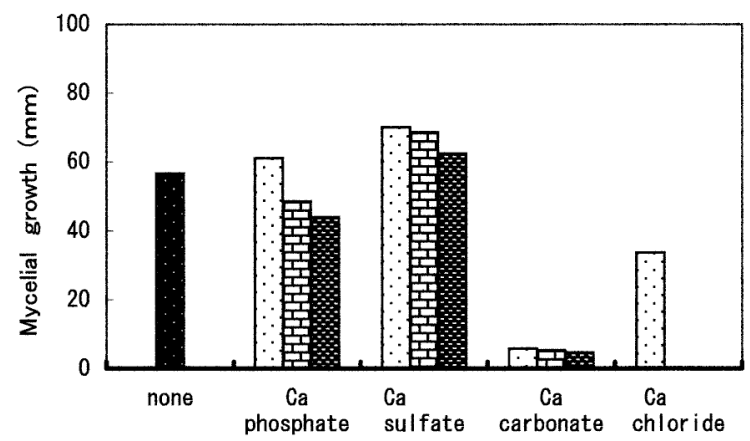

Fig. 1. Mycelial growth of A. polytricha on PSA supplemented with $\mathrm{Ca}$ salts. Marks in the Figure are as follows; $\because \because$, no addition $\square$, addition of $1 \%$; addition of $5 \%$; 7 , addition of $10 \%$. Standard deviations (mm): none 1.1 ; Ca phosphate $1 \% 0.5,5 \% 1.0,10 \% 0.6$; Ca sulfate $1 \% 2.3,5 \%$ $1.3,10 \%$ 2.0: Ca carbonate $1 \% 0.6,5 \% 0.3,10 \% \quad 0.3$; Ca chloride $1 \% 0.4$.

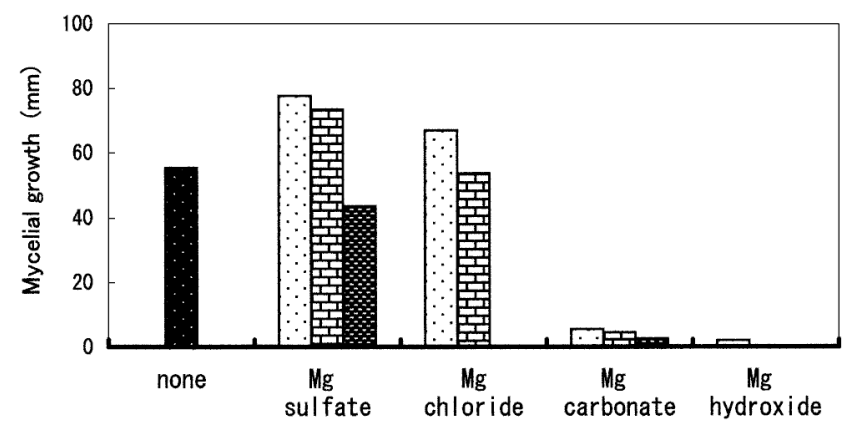

Fig. 2. Mycelial growth of A. polytricha on PSA supplemented with $\mathrm{Mg}$ salts. * Marks in the Figure are as follows: $\because \cdots$, no addition; $\bullet$, addition of $0.5 \%$; 茞, addition of $1.0 \%$, 图, addition of $5 \%$. Standard deviations (mm): none $0.9 . \mathrm{Mg}$ sulfate $0.5 \% 0.6,1 \% 0.3,5 \% 0.4 ; \mathrm{Mg}$ chloride $0.5 \% 0.5,1 \%$ 0.4 ; $\mathrm{Mg}$ carbonate $0.5 \% 0.7,1 \% \quad 0.5,5 \% 0.4 ; \mathrm{Mg}$ hydroxide $0.5 \% 0.2$.

Effect of Ca salts on the mycelial growth in the PSA Figure 1 shows the effect of diverse Ca salts on the mycelial growth on the PSA. The mycelia grew very well on PSA medium supplemented by $\mathrm{Ca}$ phosphate and $\mathrm{Ca}$ sulfate. However, the growth was suppressed remarkably when supplemented with Ca carbonate at all of the three concentrations and completely by Ca chloride at 5 and $10 \%$.

The supplementation with $1 \%$ a chloride slightly suppressed the mycelial growth, however, 5 and $10 \%$ additions did not allow any growth. Therefore, chloride ion exerts considerably high toxicity on mycelial growth of A. polytricha.

Effect of Mg salts on the mycelial growth on the PSA Figure 2 shows the effect of the mycelial growth on the supplementation with $0.5,1$, and $5 \%$ of $\mathrm{Mg}$ salts to agar medium. The supplementation of $0.5 \% \mathrm{Mg}$ sulfate and $\mathrm{Mg}$ chloride significantly increased the growth compared with non supplement. However, the growth was decreased critically by the supplementation with $5 \% \mathrm{Mg}$ chloride. It is assumed that $\mathrm{Mg}$ chloride is a considerably toxic substance to $A$. polytricha at $1 \%$ or more.

The growth was depressed remarkably by $\mathrm{Mg}$ carbonate and $\mathrm{Mg}$ hydroxide. Moreover, supplementation of $1 \%$ and $5 \% \mathrm{Mg}$ hydroxide did not allow any growth.

Effect of Ca salts on the mycelial growth on the sawdust media Figure 3 shows the effects of supplementation with 1, 5, and $10 \%$ of $\mathrm{Ca}$ salts on the mycelial growth in $\mathrm{mm}$. The addition of $\mathrm{Ca}$ phosphate did not affect the growth while $\mathrm{Ca}$ sulfate and Ca chloride remarkably suppressed it.

On the other hand, the mycelial growth was considerably increased with the addition of $\mathrm{Ca}$ carbonate. Previously it was found that the sawdust medium containing $\mathrm{Ca}$ carbonate showed notably lower initial $\mathrm{pH}$ values than that of the corresponding PSA (Tabata \& Shinohara, 1995). The observed promotion suggests that the acidic wood extracts having toxicity on fungi in a sawdust medium, such as fatty acids, aromatic compounds and terpenoids (Migita et al., 1968) were neutralized and converted to nontoxic compounds by supplementation with $\mathrm{Ca}$ carbonate. Therefore, Ca carbonate supplementation might be recommendable when softwood sawdust is used for mushroom culture. In fact, the advantage of the supplementation of a sawdust medium with $\mathrm{Ca}$ carbonate has been widely recognized in the culture of mushrooms (Balasubramanyam, 1988; Tripathi et al., 1993; Sanchez \& Royse, 2001). 
Effect of $\mathrm{Mg}$ salts on mycelial growth in the sawdust medium Figure 4 shows the effect of the supplementation of the sawdust medium with $0.5,1$, and $5 \%$ of $\mathrm{Mg}$ salts on the growth of mycelia. In contrast to the control, the supplementation with $0.5 \% \mathrm{Mg}$ carbonate and $\mathrm{Mg}$ hydroxide increased the mycelial growth. However, supplementation of $5 \% \mathrm{Mg}$ carbonate and $\mathrm{Mg}$ hydroxide did not allow any growth.

Effect of $p H$ in the medium on mycelial growth Table 1 shows the $\mathrm{pH}$ values before and after incubation of $A$. polytricha on sawdust medium supplemented with Ca salts. On the 14th day, the media were completely covered by mycelia, when the $\mathrm{pH}$ decreased by $0.3-1.5$ units from the initial. These decreases might be responsible for organic acids produced in the vegetative mycelia. Yoshida et al. (1996) showed that malic acid was the predominant organic acid detected in the vegetative mycelia.

The $\mathrm{pH}$ of the medium supplemented with $\mathrm{Mg}$ salts before and after the incubation is shown in Table 2. Most of the initial $\mathrm{pH}$ values are from 5.3-6.8 except for the higher values for 5\% supplementations of $\mathrm{Mg}$ carbonate and hydroxide, which critically inhibited the mycelial growth. The $\mathrm{pH}$ of media lowered by 0.4-1.2 units on the14th day of the cultivation except for the 5\% supplementations of $\mathrm{Mg}$ carbonate and hydroxide.

Kinjo and Kondo (1979) found that the optimum $\mathrm{pH}$ of $A$. polytricha growth is $7-8$ and that the mycelia grew over $50 \%$

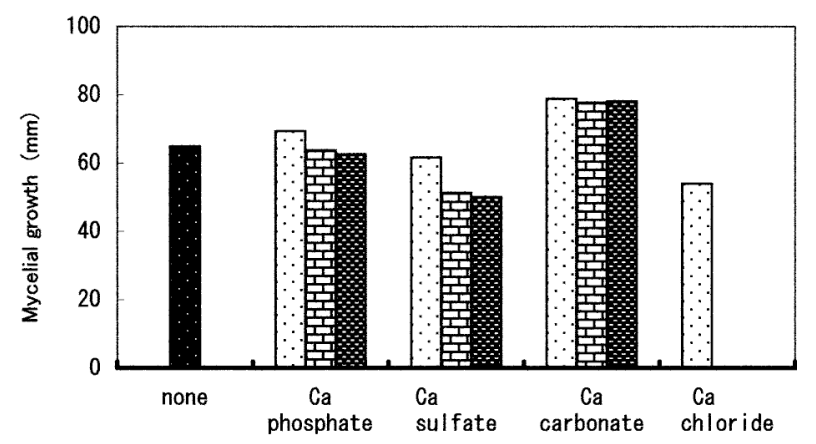

Fig. 3. Mycelial growth of A. polytricha on sawdust media supplemented with Ca salts. Marks in figure were the same as those in Fig. 1. Standard deviations (mm): none 0.5; Ca phosphate $1 \% 1.2,5 \% 2.5,10 \% 2.1$; Ca sulfate $1 \% 2.3,5 \% 2.1,10 \% 1.6 ; \mathrm{Ca}$ carbonate $1 \% 0.9,5 \% 0.4,10 \% 0.7 ; \mathrm{Ca}$ chloride $1 \% 3.7$.

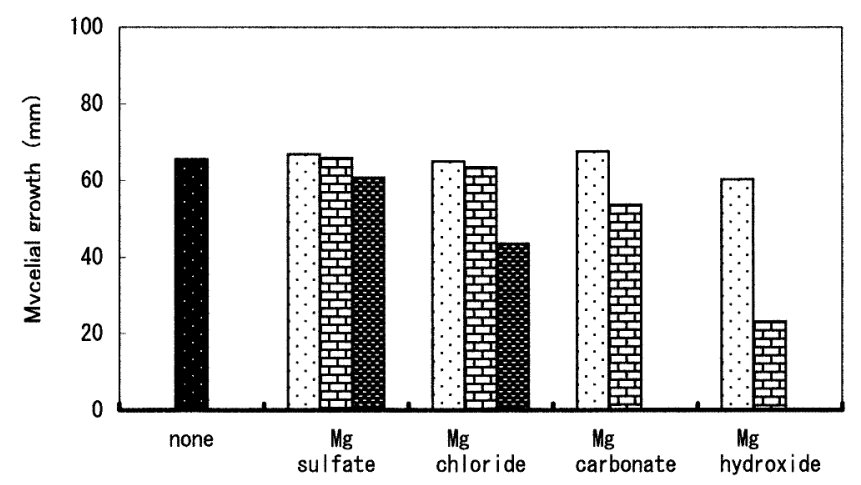

Fig. 4. Mycelial growth of A. polytricha on sawdust media supplemented with $\mathrm{Mg}$ salts. Marks in Figure were the same as those in Fig. 2. Standard deviations (mm): none 1.0 ; $\mathrm{Mg}$ sulfate $0.5 \% 1.7,1 \% 1.7,5 \% 2.3$; Mg chlorlde $0.5 \% 1.0,1 \% 1.7,5 \% 1.4 ; \mathrm{Mg}$ carbonate $0.5 \% 1.4,1 \% 2.4 \% ; \mathrm{Mg}$ hydroxide $0.5 \% 1.6,1 \% 1.3$. even in lower medium $\mathrm{pH} 4$. On the other hand, the two highest $\mathrm{pH}$ were found in the medium supplemented by $5 \% \mathrm{Mg}$ hydroxide and carbonate, 8.83 and 7.43 , respectively. The media of these $\mathrm{pH}$, at least that of the latter, must be the optimum condition; however, the growth was completely inhibited in them.

Consequently, it is concluded that the relatively high $\mathrm{pH}$ of media supplemented with these salts is not responsible for the growth inhibition. However, further study is awaited to understand the toxicity of the salts.

Absorption of $\mathrm{Ca}$ by the fruit body Based on the mycelial growth experiments on the Ca-supplemented sawdust medium, the efficiencies of $\mathrm{Ca}$ accumulation in the fruit body were studied. As Table 3 shows, only $114 \mathrm{mg}$ of $\mathrm{Ca}$ in $100 \mathrm{~g}$ of dried mushroom was found in the mushroom cultivated on a nonsupplemented sawdust medium. Supplementation with 1-10\% Ca carbonate or Ca phosphate increased the $\mathrm{Ca}$ content in the fruitbody $1.1-1.5$ times, attaining $130-173 \mathrm{mg} / 100 \mathrm{~g}$. The supplementation with $5 \% \mathrm{Ca}$ carbonate or $1 \% \mathrm{Ca}$ phosphate resulted in the highest $\mathrm{Ca}$ content.

Absorption of Mg by the fruit body The Mg contents in the fruit body are shown in Table 3. The supplementation with

Table 1. $\mathrm{pH}$ Value before and after incubation of A. polytricha on sawdust media supplemented with Ca salts.

\begin{tabular}{lcccc}
\hline \multirow{2}{*}{ Salts } & \multicolumn{4}{c}{ Supplementation } \\
\cline { 2 - 5 } & 0 & $1 \%$ & $5 \%$ & $10 \%$ \\
\hline & $5.50(4.73)$ & & & \\
Ca phosphate & & $5.56(4.87)$ & $5.55(4.93)$ & $5.51(4.97)$ \\
Ca sulfate & & $5.39(4.81)$ & $5.05(4.63)$ & $4.94(4.59)$ \\
Ca carbonate & $6.17(5.01)$ & $6.64(5.15)$ & $6.78(5.42)$ \\
Ca chloride & & $5.23(4.89)$ & $4.69(4.70)^{a)}$ & $4.52(4.52)^{a)}$ \\
\hline
\end{tabular}

The initial and final $\mathrm{pH}$ are shown without and in parenthesis, respectively. The sawdust media were incubated at $25^{\circ} \mathrm{C}$ under $85 \%$ humidity in the dark for 14 days to allow full colonization of mycelia.

${ }^{a}$ Mycelial growth was critically inhibited.

Table 2. $\mathrm{pH}$ Value before and after incubation of A. polytricha on sawdust media supplemented with $\mathrm{Mg}$ salts.

\begin{tabular}{lcccc}
\hline \multirow{2}{*}{ Salts } & \multicolumn{4}{c}{ Supplementation } \\
\cline { 2 - 5 } & 0 & $0.5 \%$ & $1 \%$ & $5 \%$ \\
\hline & $5.54(4.78)$ & & & \\
Mg sulfate & & $5.59(4.82)$ & $5.56(4.84)$ & $5.35(4.79)$ \\
Mg chloride & $5.63(4.82)$ & $5.53(4.78)$ & $5.27(4.86)$ \\
Mg carbonate & $6.25(5.19)$ & $6.39(5.37)$ & $7.43(7.40)^{a)}$ \\
Mg hydroxide & $6.40(5.33)$ & $6.83(5.67)$ & $8.83(8.70)^{a)}$ \\
\hline
\end{tabular}

Number and mark in Table are the same as those in Table 1.

Table 3. Ca contents in fruit body of A. polytricha harvested from the sawdust medium supplemented with $\mathrm{Ca}$ carbonate and $\mathrm{Ca}$ phosphate.

\begin{tabular}{lccc}
\hline Compound & $\begin{array}{c}\text { Supplementation } \\
(\%)\end{array}$ & $\begin{array}{c}\text { Ca content } \\
(\mathrm{mg} / 100 \mathrm{~g}, \text { dry weight })\end{array}$ & $\begin{array}{c}\text { Absorption } \\
\text { ratio }^{\mathrm{b}}\end{array}$ \\
\hline Ca carbonate & 1 & $142.3 \pm 2.7^{\mathrm{a}}$ & 1.2 \\
& 5 & $172.1 \pm 3.8^{\mathrm{a}}$ & 1.5 \\
Ca phosphate & 10 & $114.4 \pm 3.1^{\mathrm{a}}$ & 1 \\
& 1 & $173.3 \pm 5.4^{\mathrm{a}}$ & 1.5 \\
Control & 5 & $130.2 \pm 1.2^{\mathrm{a}}$ & 1.1 \\
\hline
\end{tabular}

${ }^{\mathrm{a}}$ Standard deviation.

${ }^{\mathrm{b}}$ The absorption ratio was obtained by dividing the calcium content of fruit body from supplemented medium with that harvested from control. 
Table 4. $\mathrm{Mg}$ contents in fruit body of A. polytricha harvested from the sawdust medium supplemented with $0.5 \%$ of $\mathrm{Mg}$ salts.

\begin{tabular}{lcc}
\hline Compound & Ca content $(\mathrm{mg} / 100 \mathrm{~g}$, dry weight $)$ & Absorption ratio \\
\hline Mg sulfate & $222.2 \pm 5.4^{\mathrm{a}}$ & 1.8 \\
Mg chloride & $280.4 \pm 6.2^{\mathrm{a}}$ & 2.2 \\
Mg carbonate & $210.1 \pm 4.1^{\mathrm{a}}$ & 1.7 \\
Mg hydroxide & $238.3 \pm 4.8^{\mathrm{a}}$ & 1.9 \\
Control & $125.1 \pm 5.0$ & - \\
\hline
\end{tabular}

${ }^{a}$ Standard deviation.

$\mathrm{Mg}$ sulfate, $\mathrm{Mg}$ chloride, $\mathrm{Mg}$ carbonate and $\mathrm{Mg}$ hydroxide increased the $\mathrm{Mg}$ content in the fruit-body 1.7-2.2 times, attaining 210-280 mg/100 g. In particular, the supplementation with $\mathrm{Mg}$ chloride resulted in the highest $\mathrm{Mg}$ content.

It is well documented that rice bran has a high $\mathrm{Mg}$ content (Idouraine et al., 1995; Claye et al., 1998). Idouraine et al. (1996) reported that the defatted rice bran they studied contained 580 and $120 \mathrm{mg} / 100 \mathrm{~g}$ of $\mathrm{Mg}$ and $\mathrm{Ca}$, respectively. The $\mathrm{Mg}$ and $\mathrm{Ca}$ contents in Japanese rice bran are reported to be 1000 and $46 \mathrm{mg} / 100 \mathrm{~g}$, respectively (Kagaku Gijutsu-cho, 1995). We found that the sawdust medium employed in this study had $75.1 \mathrm{mg}$ of $\mathrm{Ca}$ and $95.8 \mathrm{mg}$ of $\mathrm{Mg}$ in $100 \mathrm{~g}$ of the medium (wet weight). Therefore, a considerable amount of $\mathrm{Ca}$ and $\mathrm{Mg}$ was already in the culture medium before the supplementations. However, it is known that $\mathrm{Ca}$ and $\mathrm{Mg}$ in rice bran are a form of hardly soluble phytin (Hayakawa \& Igaue, 1992; Sugahara et al., 1994) and are difficult to be absorbed. From this experimental result, it is considered that the absorption of $\mathrm{Ca}$ or $\mathrm{Mg}$ from the medium is closely related to the type and concentration of supplemented diverse $\mathrm{Ca}$ and $\mathrm{Mg}$ salts.

\section{References}

Arakawa, N., Enomoto, K., Mukoyama, H., Nakajima, K., Tanabe, O. and Inagaki, C. (1977). Effect of basidiomycetes on plasma cholesterol in rats. Eiyo To Shokuryo, 30, 29-33 (in Japanese).

Balasubramanyam, R.H. (1988). Mushroom crop on willow-dust. Ind. J. Microbiol., 28, 131-132.

Cheung, P.C.K. (1997). Dietary fiber content and composition of some edible fungi determined by two methods of analysis. J. Sci. Food Agric., 73, 255-260.

Claye, S.S., Idouraine, A. and Weber, C.W. (1998). In-vitro mineral binding capacity of five fiber sources and their insoluble components for magnesium and calcium. Food Chem., 61, 333-338.

Hayakawa, T. and Igaue, I. (1992). The structure and function of phytic acid. Nippon Shokuhin Kogyo Gakkaishi, 39, 647-655 (in Japanese).

Idouraine, A., Hassani, B.Z., Claye, S.S. and Weber, C.W. (1995). In vitro binding capacity of various fiber sources for magnesium, zinc, and copper. J. Agric. Food Chem., 43, 1580-1584.

Idouraine, A., Khan, M.J. and Weber, C.W. (1996). In vitro binding capacity of wheat bran, rice bran, and oat fiber for $\mathrm{Ca}, \mathrm{Mg}, \mathrm{Cu}$, and $\mathrm{Zn}$ alone and in different combinations. J. Agric. Food Chem., 44, 2067-2072.

Idouraine, A, Khan, M.J., Kohlhepp, E.A. and Weber, C.W. (1996). In vitro mineral binding capacity of three fiber sources for $\mathrm{Ca}, \mathrm{Mg}, \mathrm{Cu}$ and Zn by two different methods. Int. J. Food Sci. Nutr., 47, 285-293.

Imazeki, R., Hongo, T. and Tsubaki, K. (1970). Common fungi of Japan in color. Hoikusha, Osaka, p. 27 (in Japanese).

Kagaku-Gijutsucho Shigen Chosa-kai. (1995). Standard Tables of Food Composition in Japan, 4th ed., Joshi Eiyo Daigaku, Tokyo, p. 58, 204-285 (in Japanese).

Kawai, H., Sugahara, T., Matsuzawa, M., Sumiyashiki, K., Aoyagi,Y. and Hosogai, Y. (1986). Mineral contents in edible mushrooms. Nip- pon Shokuhin Kogyo Gakkaishi, 33, 250-255 (in Japanese).

Kawai, H., Sugahara, T., Fujishiro, S., Matsuzawa, M., Aoyagi, Y. and Hosogai, Y. (1990). Mineral contents of edible mushrooms growing on wood. Comparison with mineral contents of mushrooms growing in soil. Nippon Shokuhin Kogyo Gakkaishi, 37, 468-473 (in Japanese).

Kinjo, K and Kondo, K (1979). Study on the cultivation culture media of basidiomycetes. III. With reference to cultural characteristics of Auricularia polytricha (Mont.) Sacc. Mokuzai Gakkaishi, 25, 799803 (in Japanese).

Lee. J.W, Lee, J.G, Do, J.H. and Sung, H.S (1995). Volatile flavor components of Korean Auricularia polytricha (Mont.) Sacc. mushroom. Han'guk Nonghwa Hakhoechi, 38, 546-548 (Chem. Abs. (1966). 124, 200616).

Lin, X. (1991). Cultivation of edible mushrooms with Acacia mearnsii. Linchan Hиахие Yu Gongye., 11, 135-141 (Chem. Abs. (1992). 116, 55463).

Mau, J.L., Wu, K.T., Wu, Y.H. and Lin, Y.P. (1998). Nonvolatile taste components of ear mushrooms. J. Agric. Food Chem., 46, 45834586.

Migita, N., Yonezawa, Y. and Kondo, T. (1968). Wood Chemistry, Vol. 1. Kyoritsushuppan, Tokyo, pp. 437-490 (in Japanese).

Misaki, A., Sone, I. and Iwata, K. (1979). Antitumor $\beta$-1,3-glucans from Auricularia species. Japan Kokai Tokkyo Koho, 79, 63,012. May. 21 (in Japanese).

Sanchez, J.E. and Royse, D.J. (2001). Adapting substrate formulas used for shiitake for production of brown Agaricus bisporus. Bioresour Technol, 77, 65-69.

Sasaki, H., Aoyagi, Y., Kasuga, A., Tanaka, Y., Matsuzawa, M. and Kawai, H. (1995). Relationships between fruit body compositions and substrates in bunashimeji [Hypsizigus marmoreus (Peck) Bigelow], nameko [Pholiota nameko (J. Ito)], and enokitake [Flammulina velutipes (Curt.: Fr.) Sing.] mushrooms cultivated on sawdust substrate beds. Nippon Shokuhin Kagaku Kogaku Kaishi, 42, 471-477 (in Japanese).

Sugahara, T., Fukuzawa, M., Aoyagi, Y., Okawa, H., Koizumi, N. and Tazokoro, T. (1994). Syokuhingakusoron, Kenpakusha, Tokyo, p 64 (in Japanese).

Tabata, T. and Shinohara, H. (1995). Absorption of calcium from calcium salts added to culture media by Hiratake (Pleurotus ostreatus (Fr.) Quel.) and Nameko (Pholiota nameko J. Ito). Nippon Shokuhin Kagaku Kogaku Kaishi, 42, 682-686 (in Japanese).

Tabata, T. and Ogura, T. (2003). Absorption of calcium and magnesium by the fruiting body of the cultivated mushroom Hypsizigus marmoreus (Peck) Bigelow from sawdust culture media. J. Food Sci., 68, 76-79.

Tamaki, Y., Kinjo, K., Onishi, T., Hongo, F., Shinjo, C. and Yaga, S. (1997). Studies on the structure, function and utilization of water soluble polysaccharides from tropical mushrooms. I. Control of serum cholesterol levels in rats by Pleurotus abalonus Han.Chen et Cheng. Mokuzai Gakkaishi, 43, 90-95 (in Japanese).

Tham, L.X., Matsuhashi, S. and Kume, T. (1999). Growth and fruit body formation of Ganoderuma lucidum on media supplemented with vanadium, selenium and germanium. Mycoscience, 40, 87-92.

Tham, L. X., Matsuhashi, S. and Kume, T. (1999). Responses of Ganoderma lucidum to heavy metals. Mycoscience, 40, 209-213.

Tripathi, K. C., Upadhyay, J. and Singh, R.K. (1993). Effect of different casing material on the growth and yield of button mushroom. Prog. Hortic., 23, 141-143.

Yasui, A., Tsutsumi, C., Takasaki, M. and Mori, T. (1988). Absorption of elements from heavy metals containing culture media by oyster mushroom (Pleurotus ostreatus (Fr.) Quel.). Nippon Shokuhin Kogyo Gakkaishi, 35, 160-165 (in Japanese).

Yoshida, H., Sugahara, T. and Hayashi, J. (1986). Free sugars, free sugar alcohols and organic acids of wild mushrooms. Nippon Shokuhin Kogyo Gakkaishi, 33, 426-433 (in Japanese).

Yoshida, H., Sasaki, H., Fujimoto, S. and Sugahara, T. (1996). The chemical components of the vegetative mycelia of basidiomycetes. Nippon Shokuhin Kogaku Kaishi, 43, 748-755 (in Japanese).

Zhou, X. and Yu, F. (2000). Antioxidative effect of Auricularia polytricha Sacc polysaccharides. Hongguo Yiyuan Yaoxue Zazhi, 20, 610-611 (Chem. Abs. (2001). 135, 40920). 